\title{
MASTER
}

\section{Summary Report of TASTEX Task J: Resin Bead Mass Spectrometry for Safeguards}
J. A. Carter
D. H. Smith
R. L. Walker 


\section{DISCLAIMER}

This report was prepared as an account of work sponsored by an agency of the United States Government. Neither the United States Government nor any agency Thereof, nor any of their employees, makes any warranty, express or implied, or assumes any legal liability or responsibility for the accuracy, completeness, or usefulness of any information, apparatus, product, or process disclosed, or represents that its use would not infringe privately owned rights. Reference herein to any specific commercial product, process, or service by trade name, trademark, manufacturer, or otherwise does not necessarily constitute or imply its endorsement, recommendation, or favoring by the United States Government or any agency thereof. The views and opinions of authors expressed herein do not necessarily state or reflect those of the United States Government or any agency thereof. 


\section{DISCLAIMER}

Portions of this document may be illegible in electronic image products. Images are produced from the best available original document. 
Printed in the United States of America. Available from National Technical Information Service

U.S. Department of Commerce 5285 Port Royal Road, Springfield, Virginia 22161

Price: Printed Copy $\$ 4.00$; Microfiche $\$ 3.00$

This report was prepared as an account of work sponsored by an agency of the United States Government. Neither the United States Government nor any agency thereof, nor any of their employees, contractors, subcontractors, or their employees, makes any warranty, express or implied, nor assumes any legal liability or responsibility for any third party's use or the results of such use of any information, apparatus, product or process disclosed in this report, nor represents that its use by such third party would not infringe privately owned rights. 
Contract No. W-7405-eng-26

Analytical Chemistry Division

SUMMARY REPORT OF TASTEX TASK J:

RESIN BEAD MASS SPECTROMETRY

FOR SAFEGUARDS

by

J. A. Carter, D. H. Smith, and

R. L. Walker

Date Published - October 1978

This work was supported by the Division of Safeguards and Security

U.S. Department of Energy and by the Program for

Technical Assistance to IAEA Safeguards

Under Interagency Agreement No. 40-633-77

NOTICE This document contains information of a preliminary nature. It is subject to rovicion or correction and therefore does not represent a final report.

OAK RIDGE NATIONAL LABURAIUKY

Oak Ridge, Tennessee 37830 operated by

UNION CARBIDE CORPORATION for the DEPARTMENT OF ENERGY 
THIS PAGE

\section{WAS INTENTIONALLY \\ LEFT BLANK}




\section{TABLE OF CONTENTS}

\section{Page}

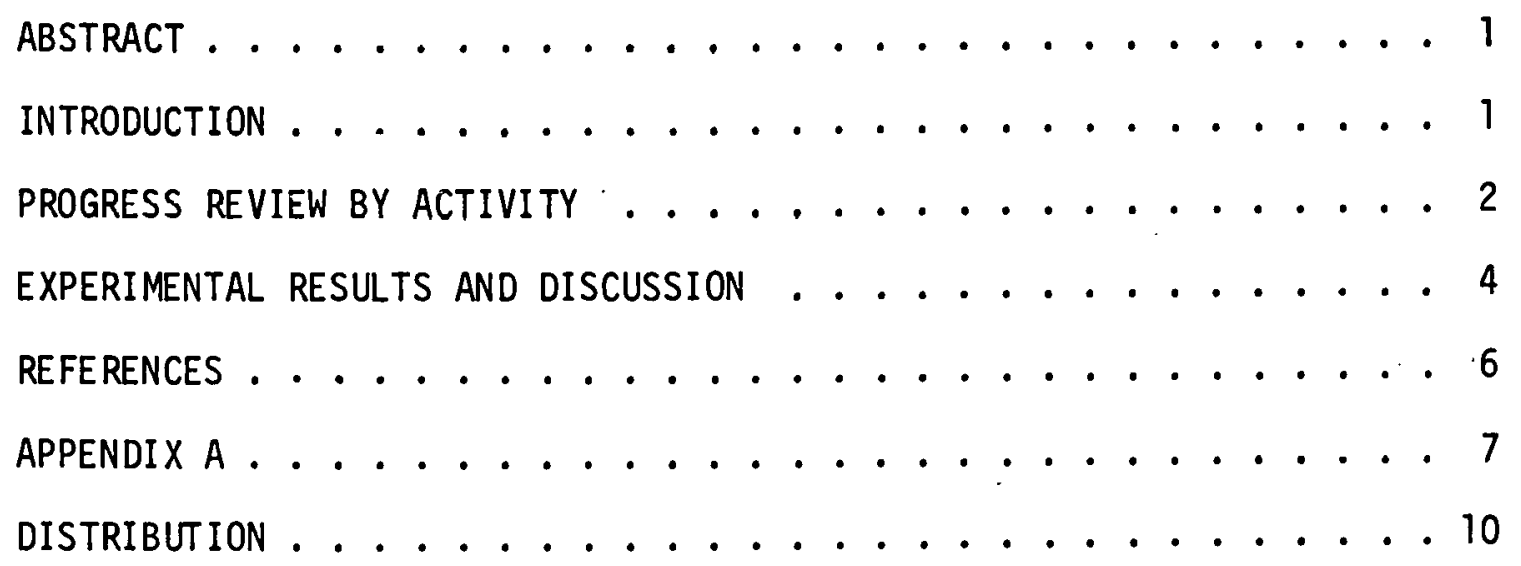




\section{SUMMARY REPORT OF TASTEX TASK J:}

RESIN BEAD MASS SPECTROMETRY FOR SAFEGUARDS

J. A. Carter, D. H. Smith, and R. L. Walker

\section{ABSTRACT}

Our involvement with the TASTEX program is described in Task $\mathrm{J}$; progress on this task during FY-1978 is described in this summary. This task involves collaboration with the Japanese at the Tokai reprocessing facility to evolve a sampling scheme suitable for use by International Atomic Energy Agency inspectors. The samples would be taken on resin beads and shipped in that form; because of the small quantities of material involved in this sampling technique, heal th hazards during transport are eliminated and costs minimized.

During a conference at Tokai, the Japanese familiarized us with their reprocessing procedure, and consultations with them led to a sampling protocol that would inconvenience them very little.

At Japanese request, we have made measurements and calculations of the amount of radiation from typical beads, and present recommendations as to the number of beads that can safely be handled in a single shipment. Tables of our results are included.

\section{INTRODUCTION}

Task $\mathrm{J}$ involves introducing Japanese staff members at the Power Reactor and Nuclear Fuel Development Corporation (PNC) Reprocessing Plant at Tokai to the resin bead sampling technique to facilitate their interaction with IAEA sampling crews. The overall goal is to demonstrate the applicability and oversee the implementation of the resin bead technique for determining elemental concentrations and isotopic compositions of $U$ and $\mathrm{Pu}$ in input and product solutions. The res in bead technique involves absorption of $U$ and $\mathrm{Pu}$ on individual anion resin beads; complete separation from fission products is achieved. Samples can be shipped on the beads without needing special shielding because of the small quantities of material $\left(i 10^{-9} \mathrm{~g}\right)$ involved. Each bead constitutes a single 
sample for isotopic analysis on a properly equipped mass spectrometer. Plutonium and uranium can be sequentially analyzed $(1-3)$ from the same bead, or the $U$ can be stripped off and each element analyzed individually.

For mass spectrometric analysis, it is essential that the instrument be equipped with a pulse-counting detection system because of the small quantities involved. Most of our analyses at ORNL are done on instruments of two or three magnetic and/or electrostatic stages, (4) but we have recently demonstrated that a single stage mass spectrometer equipped with pulse counting can readily analyze samples from resin beads.

Quantitative results can be obtained by this technique by spiking an al iquot of the sample with enriched ${ }^{233} \mathrm{U}$ and ${ }^{242} \mathrm{Pu}$ and equilibrating samples and spike solutions before introduction of resin beads.

The basic requirement of Task $J$ involved familiarizing ourselves with the Tokai operation and, together with the Japanese, evolving a suitable sampling protocol that could be implemented by IAEA inspectors. Specific aspects of the task required seminars suitable for foreign nationals to be prepared, to train Tokai staff members at Oak Ridge, to analyze samples taken in Japan, and to prepare a final report. Progress on each item in the task is described below.

\section{PROGRESS REVIEW BY ACTIVITY}

Activiey A:

Develop familiarity with sample preparation procedures at PNC Tokai plant and review IAEA needs for sample exchange between Tokai and SAL. This was accomplished by a visit of two ORNL staff members to Tokai on June 19-22, 1978. (6) A tour of the laboratory was made, and a detailed description of their procedure was obtained. Each step in their procedure was reviewed with their chemists and mass spectroscopists.

Activity B:

Develop, in collaboration with the Japanese, a proposed work plan for implementation of this technique. Submit to ISPO/IAEA for review and comment. Consultations with the Japanese led to agreement on two alternative sampling schemes. (6) There are two steps in their procedure at which samples may conveniently be taken. One is in a hot cell; the Japanese are 
going to investigate the feasibility of performing the necessary operations with remote manipulators. If this proves impracticable, samples will be introduced to the beads following their removal as purified fractions from the hot cell into a glove box. It appears that the latter will be more likely since Japanese regulations prohibit removal of material with $>1.25 \mathrm{mr} / \mathrm{hr} \beta$ and $\gamma$ activity.

\section{Activity C:}

Develop descriptive material on the resin bead technique suitable for presentation at a seminar for foreign nationals. The seminar was presented twice in Japan (at PNC and JAERI) and can be presented at any time upon ISPO/DSS request. It is a talk with slides lasting about 30 minutes. In addition, a "cook book" describing the practical aspects of the resin bead technique has been written, ${ }^{(3)}$ and several copies were distributed to the Japanese.

Activity D:

ORNL staff members will present technical seminars to the Tokai staff on mass spectrometry requirements, resin bead preparation, and data acquisition and computation. Our seminar in Activity $\mathrm{C}$ was expanded to include this information. In addition, extensive discussions with the Japanese mass spectrometry staff covered these items in detail.

Activity E:

Train two Tokai staff members and/or IAEA inspectors in the practical application of resin bead sample loading. The necessary forms required by U. S. governmental agencies were given to the Japanese. This activity is scheduled for October/November, 1978, and will last 6-8 weeks. We have been notified by ISPO that K. Kagami and Shigenori Irinouchi will come to ORNL for training. If clearance can be arranged, the expected training period will be from October 30 through December 1, 1978.

\section{Activity F:}

Provide the follow-up test and evaluation support to Japan and IAEA during initial period of implementation of the resin bead techniques at Tokai. A schedule for this and other operations was agreed upon with the Japanese and included as Appendix A (reproduced from ORNL/FTR-401). This activity will involve taking samples at Tokai by Japanese personnel and 
shipping them to ORNL for analysis. The tentative completion date is May, 1979. Experience with similar samples with IAEA indicates that a trouble-free procedure for sample shipping needs to be devised.

Activity G:

Prepare a final report. This is currently scheduled for June, 1979.

\section{EXPERIMENTAL RESULTS AND DISCUSSION}

At the meeting in Japan, we agreed to investigate the activity on resin beads so that safe transportation mechanisms can be established. The results of our calculations are given in Tables 1 and 2 .

Table 1. Basic Information for Radiation Protection

\begin{tabular}{|c|c|c|c|}
\hline Radionuclide & Activity, $\mu \mathrm{C}^{\dagger^{*}}$ & $\begin{array}{c}\text { Specific } \\
\text { activity (SA) } \\
\mathrm{C} / \mathrm{g} \\
\end{array}$ & $\begin{array}{l}\text { Wt. permissible } \\
\text { for ea. nuclide, } \mathrm{g}\end{array}$ \\
\hline $233 U$ & -1 & $9.51 \times 10^{-3}$ & $1.05 \times 10^{-4}$ \\
\hline $234_{U}$ & 1 & $6.29 \times 10^{-3}$ & $1.59 \times 10^{-4}$ \\
\hline $235 U$ & 1 & $2.14 \times 10^{-6}$ & 0.467 \\
\hline $236 U$ & 1 & $6.50 \times 10^{-5}$ & $1.54 \times 10^{-2}$ \\
\hline $238 U$ & 1 & $3.36 \times 10^{-7}$ & 2.98 \\
\hline $237_{\mathrm{Np}}$ & 1 & $6.88 \times 10^{-4}$ & $1.45 \times 10^{-3}$ \\
\hline${ }^{236} \mathrm{Pu}$ & $0.1 \star \star$ & $5.63 \times 10^{2}$ & $0.177 \times 10^{-9}$ \\
\hline${ }^{238} \mathrm{Pu}$ & 0.1 & 16.8 & $5.95 \times 10^{-9}$ \\
\hline${ }^{239} \mathrm{Pu}$ & 0.1 & $6.17 \times 10^{-2}$ & $1.62 \times 10^{-6}$ \\
\hline${ }^{240} \mathrm{Pu}$ & 0.1 & $2.27 \times 10^{-1}$ & $0.441 \times 10^{-6}$ \\
\hline${ }^{24} 1_{\mathrm{Pu}}$ & 1 & $1.01 \times 10^{2}$ & $9.88 \times 10^{-9}$ \\
\hline${ }^{242} \mathrm{Pu}$ & 0.1 & $2.97 \times 10^{-3}$ & $33.7 \times 10^{-6}$ \\
\hline${ }^{244} \mathrm{Pu}$ & $1 * \star$ & $1.77 \times 10^{-5}$ & $0.56 \times 10^{-3}$ \\
\hline
\end{tabular}

* Maximum permissible.

Data from Basic Safety Standards for Radiation Protection, Safety Series No. 9, IAEA, 1962. **Estimated activity. 
Table 2. Resin Bead Plutonium Activity for LWR Fuel Solutions (Typical Loading One Nanogram Per Bead)

$\begin{array}{lcccc}\text { Nuclide } & \begin{array}{c}\text { At. } \% \text { of } \\ \text { element }\end{array} & \begin{array}{c}\text { IAEA } \\ \text { permissible } \\ \text { quantity, ng }\end{array} & \begin{array}{c}\text { Amount } \\ \text { per bead, ng }\end{array} & \begin{array}{c}\% \text { of } \\ \text { permissible }\end{array} \\ \begin{array}{l}236 \mathrm{Pu} \\ 238\end{array} & 5 \times 10^{-6} & 0.18 & 5 \times 10^{-8} & 2.8 \times 10^{-5} \\ { }^{23 u} & 1.5 & 5.95 & 0.015 & 0.25 \\ 239 \mathrm{Pu} & 58 & 1,620 & 0.58 & 0.036 \\ 240 \mathrm{Pu} & 24 & 441 & 0.24 & 0.054 \\ 241_{\mathrm{Pu}} & 11 & 9.88 & 0.11 & 1.11 \\ 242 \mathrm{Pu} & 5.5 & 33,700 & 0.055 & 1.6 \times 10^{-4} \\ 244 \mathrm{Pu} & <5 \times 10^{-4} & 560,000 & <5 \times 10^{-6} & <1 \times 10^{-9}\end{array}$

From the data on permissible limits in Table 1 and the expected $\mathrm{Pu}$ isotopic concentration in dissolver solutions of typical LWR fuels $(30,000$ megawatts/ton burnup), the isotope that limits the number of beads in a shipment is ${ }^{241} \mathrm{Pu}$. (See Table 2.) Summing al1 isotopes gives $1.45 \%$ of the maximum permissible Pu per bead, which means that a total of 69 beads containing one nanogram each of $\mathrm{Pu}$ and $\mathrm{U}$ are required before the maximum permissible level is approached. We therefore feel that it is possible to ship batches of 10 to 20 beads without remotely exceeding any of the permissible limits established by IAEA.

We measured the $\beta-\gamma$ activity from beads loaded with a typical LWR dissolver solution $(30,000$ megawatts/ton). The value obtained was $3.5 \times$ $10^{-6} \mathrm{mr} / \mathrm{hr} / \mathrm{bead}$, which is far below any current limitation on activity and emphasizes the safety margin if shipments are restricted to $10-20$ beads each. 


\section{REFERENCES CITED}

1. R. L. Walker, R. E. Eby, C. A. Pritchard, and J. A. Carter, Anal. Lett. I, 563 (1974).

2. J. A. Carter, R. L. Walker, R. E. Eby, and C. A. Pritchard, Int. Symp. on the Safeguarding of Nuclear Materials, Vienna, Austria, IAEA-SM201/9, 1976.

3. R. L. Walker, C. A. Pritchard, J. A. Carter, and D. H. Smith, USERDA Report ORNL/TM-5505, July, 1976.

4. D. H. Smith, W. H. Christie, H. S. Mckown, R. L. Walker, and G. R. Herte1, Int. J. Mass Spectrom. Ion Phys. 10, 343 (1972).

5. D. H. Smith, R. L. Walker, L. K. Bertram, and J. A. Carter, USDOE Report ORNL/TM-6563, September, 1978.

6. J. A. Carter and D. H. Smith, USDOE Report ORNL/FTR-401, June, 1978. 
Appendix A

Meeting at PNC, Tokai, Japan, June 19, 20, 1978

Task J: Resin Bead Sampling and Analytical Techniques

Interested parties participating in the discussion included staff members as indicated below:

\begin{tabular}{l} 
PNC \\
\hline N. Tsuji \\
K. Miyahara \\
Y. Asakura* \\
K. Kagami \\
ORNL \\
\hline
\end{tabular}

J. Carter*

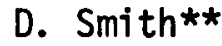

*Co-Chai rman

**Secretary

\begin{tabular}{l} 
JAERI \\
\hline H. Okashita \\
H. Umezawa \\
S. Okazaki \\
NMCC \\
\hline
\end{tabular}

M. Takahashi

$\mathrm{J}-1$ : Very little in the way of special facilities and instruments will be required at PNC. PNC will investigate the possibility of splitting the sample in step 9 of their procedure (attached) and introducing the sample to the resin beads in the hot cell. This will require adjusting the acid concentration $\left(8 \mathrm{M} \mathrm{HNO}_{3}\right)$ and $\mathrm{U}$ and $\mathrm{Pu}$ concentrations (1 $\mathrm{ng}$ Pu per bead). If manipulation of the beads inside a hot cell proves too difficult, adsorption of samples onto resin beads would be introduced in step 10 of the PNC analytical procedure.

At this point the samples have been removed from the hot cell and all subsequent operations can be performed in fume hoods or glove boxes. There are two viable al ternatives for preparation of the samples for shipment:

1. To combine a small amount of $U$ and Pu into one solution which should be about $8 \mathrm{M} \mathrm{HNO}_{3}$ and contain appropriate amounts of $U$ and $\mathrm{Pu}$; this solution could then be exposed to resin beads.

2. To adjust smala amounts of $U$ and $\mathrm{Pu}$ (2 solutions) to $8 \mathrm{M} \mathrm{HNO}_{3}$ and expose them individually to resin beads. The only special equipment required in the above procedure is the small polyethylene funnels and teflon plugs. Examples of all special equipment and tools were provided, and al ternative modifications were discussed. 
J-2: Implementation of the technique at PNC will require different equipment, depending upon the extent of involvement of PNC with the mechanics of the resin bead technique. One question to be answered is whether or not it is feasible to ship samples in the polyethylene funnels. If it is possible to do so, PNC need not develop the capability of manipulating individual beads. This form of shipping may necessitate strictly limiting the number of beads in a single funnel to conform to IAEA standards.

If it is not feasible to ship the beads in funnels, an alternative must be found. A technique that has worked in the past is to affix a number of beads to a glass microscope slide with collodion and ship the slide. If this technique is adopted, it will be necessary for PNC to transfer individual beads from the funnel to the slide with special micro-tools such as those brought by ORNL to PNC. For this operation, a low power ( $260 \mathrm{X})$ microscope will be needed.

J-3: Conversion of the Nucilide mass spectrometers will be necessary if resin bead samples are to be analyzed at PNC: This would involve installation of a pulse-counting detection system, which requires an electron multiplier and associated fast counting electronic equipment.

This conversion is necessary because of the small ( $\sim \mathrm{ng}$ ) samples involved. PNC must make the decision as to whether such a conversion is desirable or feasible within their operational demands.

The following tentative schedule was agreed upon with regard to future PNC/ORNL collaboration in resin bead technology. JAERI will add in the coming fiscal year a new mass spectrometer with hopes of adding pulse counting.

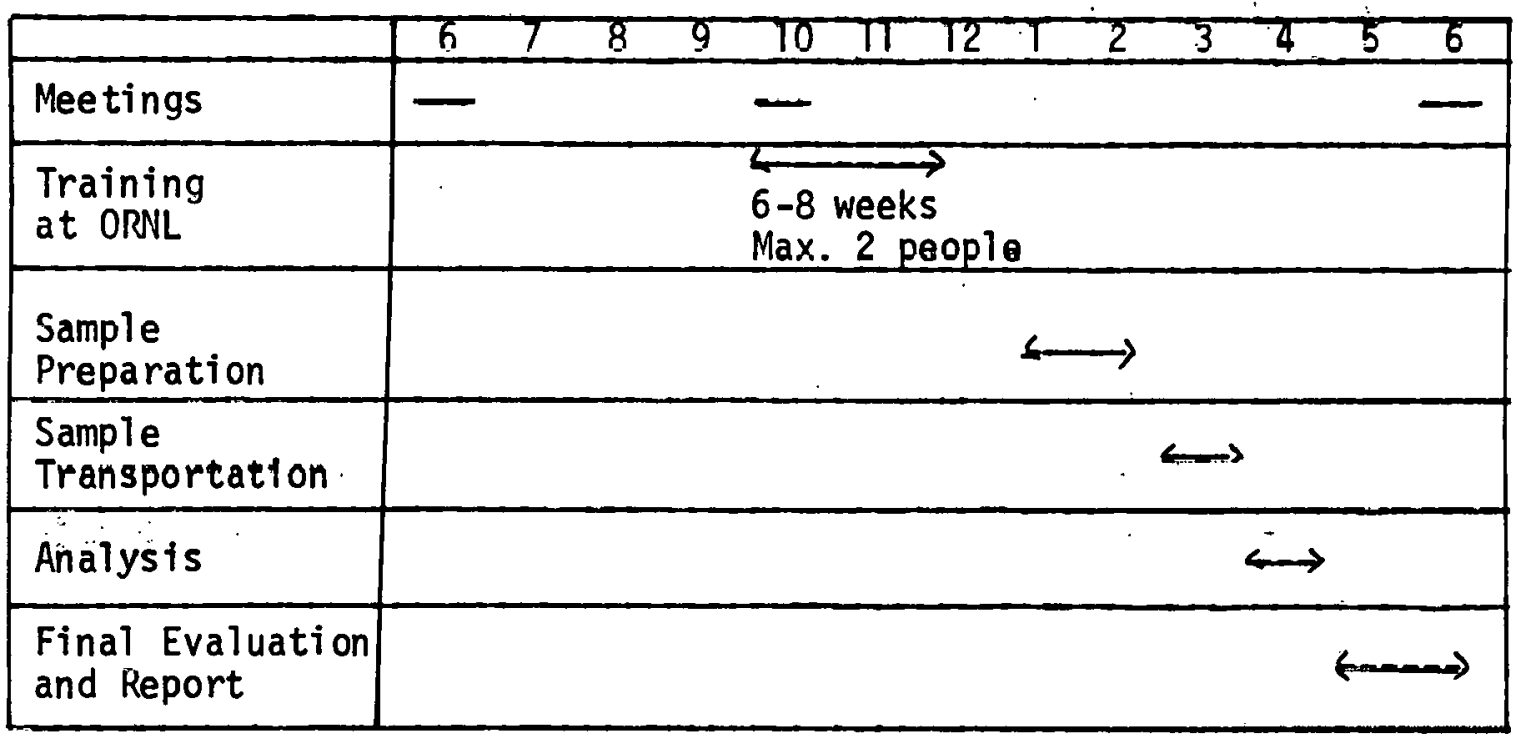

NMCC also interested in adding pulse counting to new VG mass spectrometer. 
Evaluation of the technique will involve preparation of 5 samples (plus one control) by PNC for shipping to ORNL, where mass spectrometric analyses will be performed in duplicate on spiked and unspiked $U$ and $\mathrm{Pu}$.

Determination of $U, P u$ Concentration and Isotopic Abundances (Isotopic dilution mass spectrometry)

Procedure (PNC)

1. Take an aliquot of the sample.

2. Dilute the sample with $3 \mathrm{M} \mathrm{HNO}_{3}$ (about 100 times).

3. Take an aliquot of the diluted sample.

4. Add an aliquot of the $U$, Pu mix spike solution and mix well. (volume system)

5. Add ferrous solution.

6. Heat about $70^{\circ} \mathrm{C}$.

7. Add nitrite solution and evaporate to near dryness.

8. Dissolve the residue in $250 \mu \mathrm{l}$ of $8 \mathrm{M} \mathrm{HNO}_{3}$.

9. U, Pu, FP separate by ion exchange.

10. Purification $U, P U$ fraction by ion exchange.

11. Loading $U$, Pu fraction on the triple filament.

12. Isotopic analys is by mass spectrometry.*

13. Calculations.

*Mass spectrometer.

(Nucli de 12-90-Su, 2) 


\section{THIS PAGE WAS INTENTIONALLY LEFT BLANK}


ORNL/TM-6612

ISPO-39

Distribution

\section{Internal}

1-10. J. A. Carter

11. D. E. Ferguson

12. D. L. Mason

13. H. Postma

14. W. D. Shults

1524 . D. H. Smith

25. D. B. Trauger

26-35. R. L. Walker

36. J. C. White
37. A. Zucker

38-39. Central Research Library

40. ORNL-Y-12 Technical Library, Document Reference Section

41. Laboratory Records-RC

42. Laboratory Records

43. ORNL Patent Office

\section{External}

DOE, Washington

44. J. A. Goleb

45. G. A. Hammond

46. D. M. Kurr

47. H. E. Lyon

48. S. C. T. McDowell

DOE, ORO

49. J. A. Lenhard

50. T. W. White, Jr.

51. D. S. Zachry, Jr.

International Safeguards Project office (ISPO), Brookhaven, NY

52. G. L. Booman

53. L. Green

54. J. G. Stangby

DOE, Idaho $\mathrm{Fa}$ l1s

54. C. E. Johnson

IAEA, Vienna, Austria

55. A. von Baeckmann 
56. Director, Research and Technical Support Division, DOE-ORO 57-84. Technical Information Center, Oak Ridge, Tennessee 37830 